\title{
QUALITATIVE ANALYSIS OF MAINTENANCE AND SERVICES CARRIED OUT IN A REPAIR PLANT ON THE EXAMPLE OF A MULTI-PURPOSE AIRCRAFT
}

\author{
ANALIZA JAKOŚCI OBSLUG I NAPRAW \\ REALIZOWANYCH W ZAKLADZIE REMONTOWYM \\ NA PRZYKLADZIE WIELOZADANIOWEGO STATKU \\ POWIETRZNEGO
}

\author{
Piotr Woźny \\ WZL-Military Aviation Works No. 2 S.A. \\ e-mail:metrologia@wzl2.mil.pl
}

\begin{abstract}
The article presents revealed failures and damages of the multi-task aircraft (ACFT) reported by users to the service organization, aimed at assessing and removing them. In the course of the analysis process, damages and malfunctions were grouped, depending on aviation specialities. A review was conducted that targeted occurring malfunctions and damages in a set of ACFT of the same type, over a twelve-year operational period. In the assessed period, trend lines were determined, showing a drop in the number of accepted claims submitted by ACFT users.
\end{abstract}

Keywords: operation, malfunction, damage, aircraft

Streszczenie. $W$ artykule przedstawiono ujawnione niesprawności i uszkodzenia wielozadaniowego statku powietrznego (SP) zgłoszonych przez użytkowników do organizacji obstugowej $w$ celu ich oceny oraz usunięcia. $W$ procesie analizy pogrupowano uszkodzenia i niesprawności w zależności od specjalności lotniczych. Przeprowadzono przegląd występujących niesprawności i uszkodzeń dla zbioru SP tego samego typu $w$ dwunastoletnim okresie eksploatacyjnym. W ocenianym przedziale czasu określono linie trendu ukazując spadek liczby uznanych reklamacji zgłaszanych przez użytkowników SP.

Stowa kluczowe: eksploatacja, niesprawność, uszkodzenie, statek powietrzny, 
Qualitative analysis of maintenance and services carried out in a repair plant... Analiza jakości obstug i napraw realizowanych $w$ zaktadzie remontowym...

\section{Introduction}

Maintaining a high quality level is the basic way to increase the value of products and services to such a level that they stand out from the ones offered by competition. Each enterprise aims for manufacturing products and providing services with a high level of quality, meaning that the values of their features are higher than average, in a degree ensuring meeting customer expectations. Quality features are an expression of the social viability of the product. A product's quality is a set of its essential characteristics related to the intended purpose and use compatible with the requirements set out by recipients and users. [8]. A product of a desired quality is a reliable and safe for the user. The tasks associated with keeping a product (object) in a state of suitability for use are carried out in operation (inspections and maintenances), as well as repair systems (periodic maintenance, overhauls). Maintenance and repairs of the object are carried out by a service and repair organization. Requirements regarding the managements system at those organizations are stipulated by relevant regulations. In the field of aviation, these regulations were marked in many countries as Part 145 and Part 43 [8]. An important factor impacting the quality of a technical object, e.g. aircraft in-service, are expenditures associated with the process of designing, constructing, producing and repairing. A properly running process, diversifies, consecutively [7, 9]:

- developing structural conditions that need to be met in order for the product to be suitable for flight. The designing system also prepares a manual of safe operation, as well as maintenance and repair manuals restoring its airworthiness, lost due to damage or malfunction,

- manufacturing of the product according to terms of construction, using a production technology approved during the certification process,

- using the product by the user, as per the manual and limitations defined by the design system,

- restoration by the maintenance system, of airworthiness of the product, according to terms of operation, after its loss, due to damage or failure.

A diagram of the maintenance and repair subsystem (fig. 1) shows the flow of information between subsystems of the technical object's life cycle. It is desirable for all subsystems performing individual tasks to carry out feedback analysis of information for users of a technical object $[3,6,7]$.

The entire activity of the ACFT maintenance and repair system is treated as a standardization element. Standards of the ISO 9000 series are universal. They can be applied in any production, commercial or logistics organization [3, 4]. Such versatility means that they can be successfully applied in organizing the ACFT subsystem of maintenance and repairs. Requirements useful for the maintenance and repair subsystem include, i.a., standards PN-EN ISO 9001:2008 and PN-EN ISO 9004:2009 [8], which contain an important provision stipulating that for effective and efficient operation, an organization should identify numerous interrelated processes and manage them. 


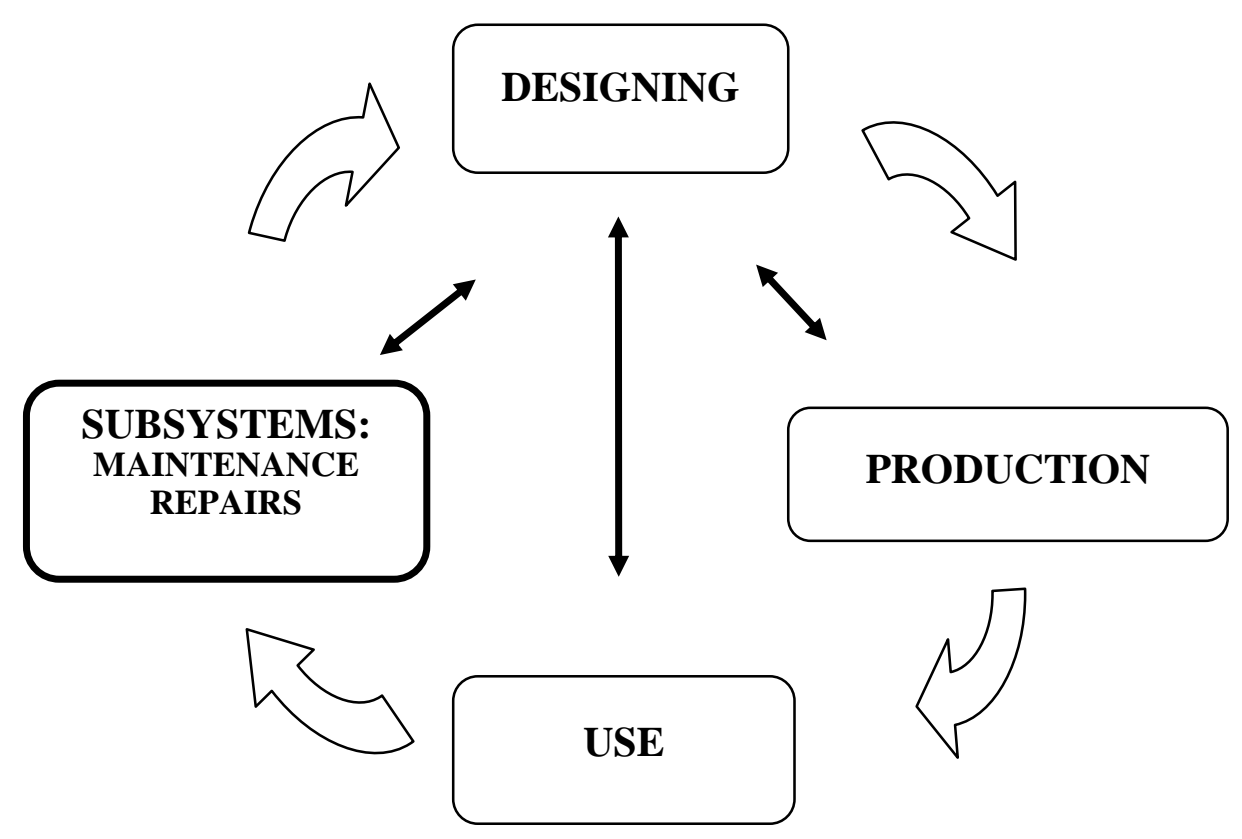

Fig. 1. Location of maintenance and repair subsystems in the life cycle of a technical object [9].

The fact of a quality management system in a company incorporating such an approach, stresses the importance of $[6,10]$ :

- understanding and meeting requirements,

- the need to consider processes in terms of added value,

- obtaining results regarding functioning and efficiency of the process,

- constant improvement of the process on the basis of an objective measurement.

The basic standard defining requirements for the quality management system is PN-EN ISO 9001:2008. It stipulates the minimum requirements that need to be met by a quality management system of a company that wants to present its ability to supply a product in accordance with user requirement.

Proper description and examination of malfunctions and damages, detection of the actual cause of their creation, is critical to improving aviation structures and method, procedures and tools for maintaining ACFT airworthiness. An important issue in the ACFT operational process is the durability analysis of their structural components. Identification of the causes of the damages plays an important role in maintaining a high level of operational reliability of an ACFT. ACFT damages concern both, the objects' construction, as well as its particular elements and 
Qualitative analysis of maintenance and services carried out in a repair plant... Analiza jakości obstug i napraw realizowanych $w$ zaktadzie remontowym...

assemblies. It is important to continuously develop methods of assessing the durability of the ACFT structure $[6,10,11]$. An ACFT should be used in accordance with its intended purpose and developed operational documentation. Exceeding limit values of operating factors impacting an ACFT causes the damages.

These factors lead to exceeding mechanical, thermal and electromagnetic loads [8]. The destructive impact of damages is the transition of an ACFT element from the state of airworthiness to incapability or partial incapability due to exceeding allowable limit values defining that element $[1,2,3]$. Appearance of damage depends on factors inside the object, operational environment and operating staff. Such an important parameter is the operational lifetime of the ACFT. The term operation is understood as the use and maintenance of devices. In this sense, ACFT is in-service both, when carrying out aviation tasks, as well as when it is stored or handled and repaired [7]. In civilian transport systems, the run time of an ACFT may be $50-80 \%$ of the day. In the military system, an aircraft spends most of its time in storage or awaiting for the performance of a task. In these states, the appearance of malfunctions and damages is highly influenced by external factors, i.e., weather conditions, developing ageing process, corrosion, stress, thermal, etc. Percentages of damages in military aviation over a period of one year, divided by aviation specialities and causes are presented in figures 2 and 3.

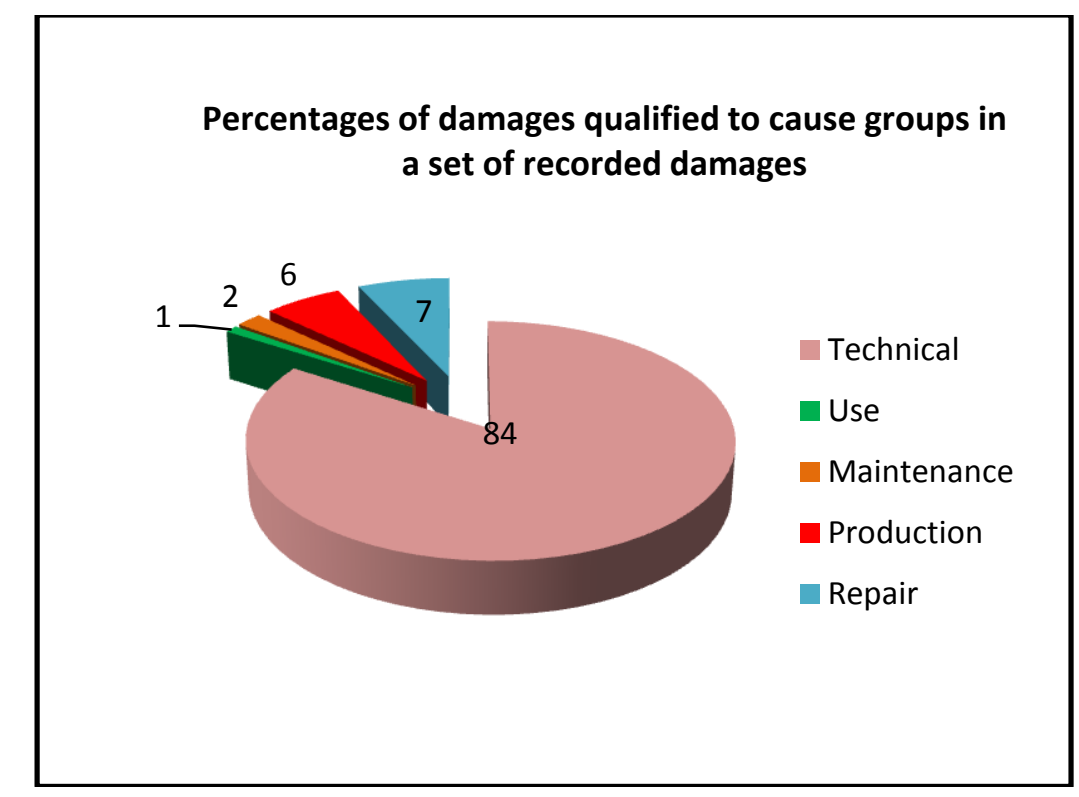

Fig. 2. Percentages of damages qualified to cause groups of damages in military aviation over a period of one year [1]. 


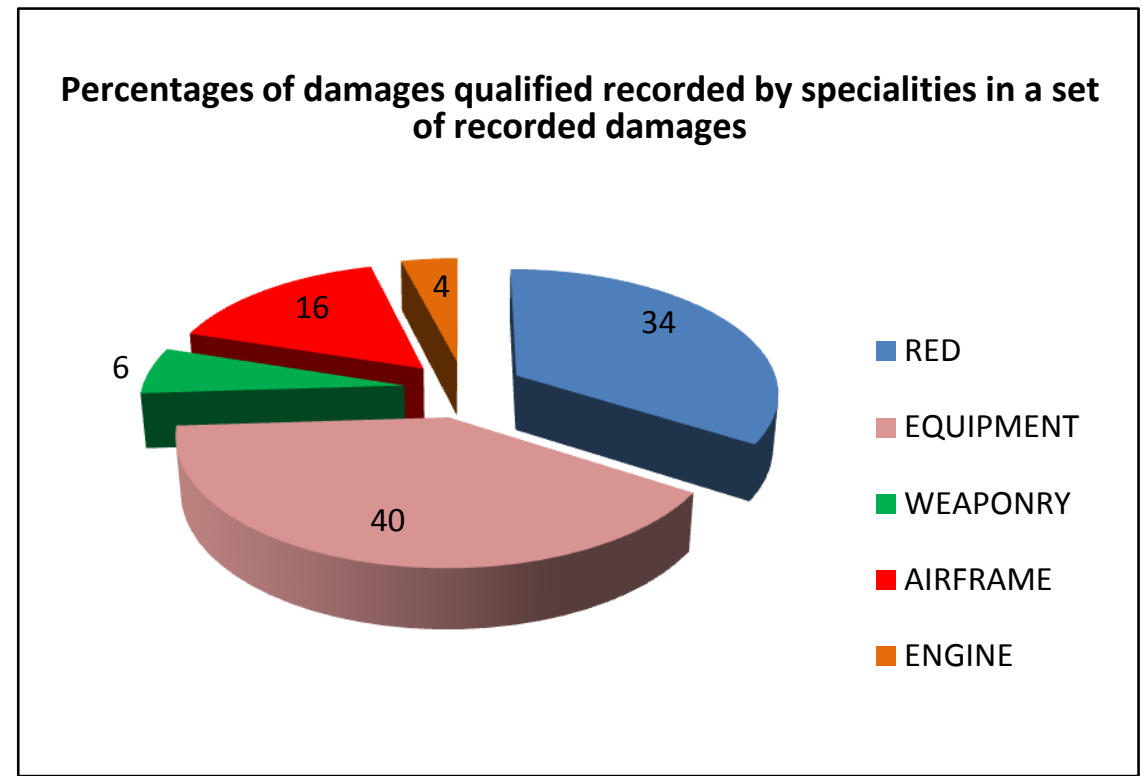

Fig. 3. Percentages of damages divided by aviation specialities in military aviation over a period of one year [1].

\section{Damages recorded by a maintenance organization of a multi-purpose ACFT on the basis of WZL-2}

Tasks associated with maintaining ACFT airworthiness in terms of removing damages are carried out by highly specialized repair companies. Due to high safety requirements, the subsystem of ACFT maintenance and repairs must ensure reliability, accuracy and quality of performed works associated with removing failures. State of ACFT repair in the maintenance and repair subsystem, is a state in which the damaged technical object is in repair stations and is subject to actions aimed at restoring its task worthiness [4, 9]. Companies carrying out repairs and overhauls of ACFT are organizationally divided into departments performing tasks in the field of a defined aviation speciality. Individual departments are responsible for removing reported damages. The analysis subject is a set of damages to an ACFT of one type operated over a twelve-year period. Data is obtained from the system collecting information about malfunctions and damages that functions within the company carrying out maintenance and repairs of the investigated ACFT. The graph in fig. 4 shows a percentage of disclosed defects that occurred during the ACFT lifetime. 
Qualitative analysis of maintenance and services carried out in a repair plant... Analiza jakości obstug i napraw realizowanych $w$ zaktadzie remontowym...

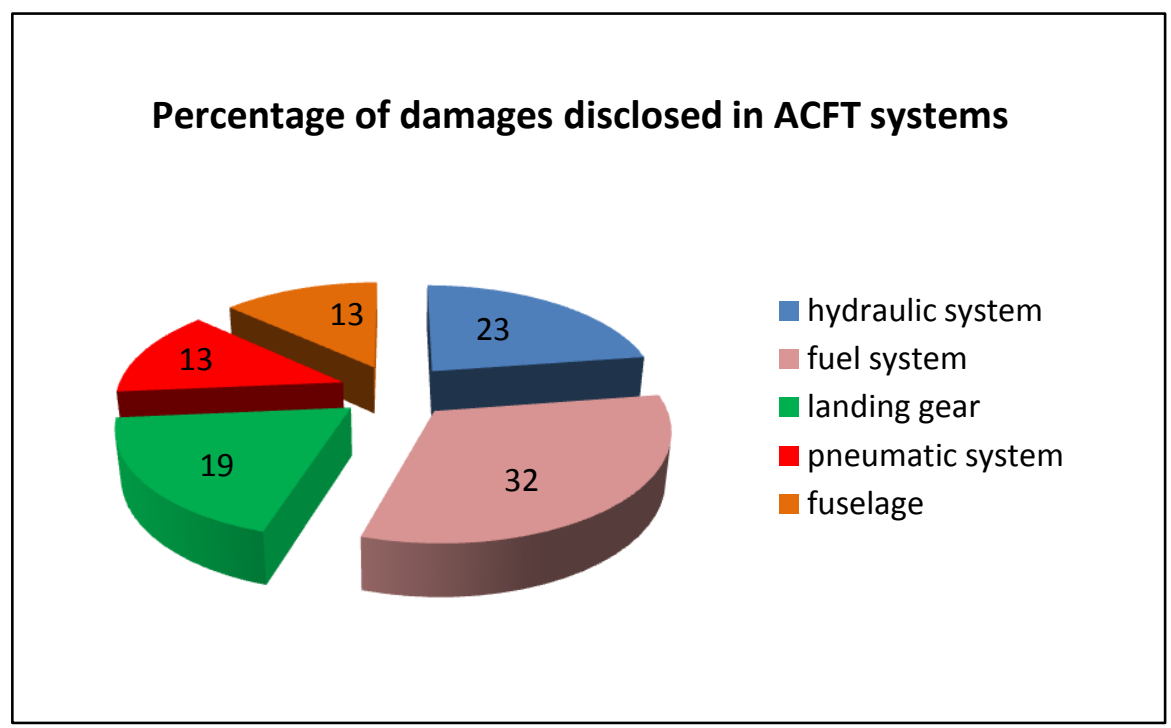

Fig. 4. Percentages of damages over 12 years for a set of one ACFT type [own elaboration on the basis of WZL-2 S.A reports.].

The graph in fig. 5 shows the share of damages that were reported to be repaired by specialized departments of repair companies over 12 years, performed for one ACFT type.

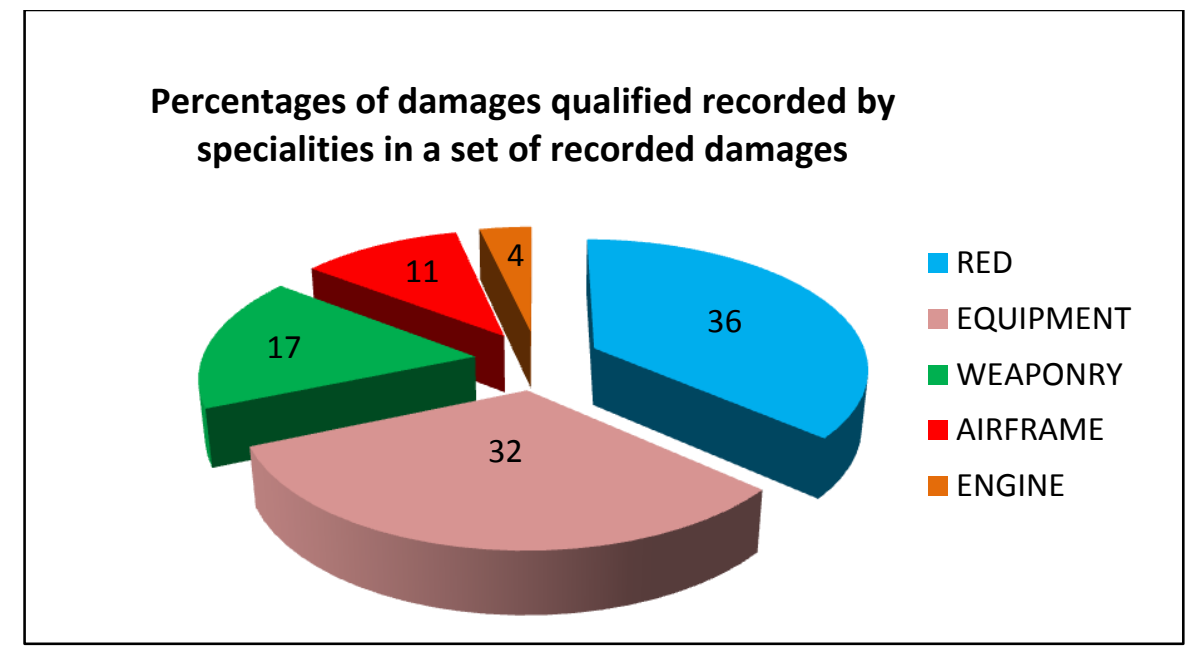

Fig. 5. Percentage of damages reported and recorded for repair by individual departments in a repair company, over 12 years, for one ACFT type [own elaboration on the basis of WZL-2 S.A. reports]. 


\section{Assessment of maintenance and repair quality of ACFT carried out at WZL-2 S.A.}

Over the analysed period, observed was a decreasing tendency in damages and malfunctions due to improper maintenance or repair (fig. 6). The trend line over the evaluated operation period shows a drop in the number of accepted claims submitted by ACFT users. In this case we used second degree polynomial regression. The obtained coefficient of determination $\mathrm{R} 2=0,835$ explicitly confirms the strong relation between the performance period and the number of claims reported by users of the ACFT. A significant decrease of clams since 2007 was observed in the course of the analysis of damage amount. An important factor influencing that phenomenon is the impact of the Departmental Quality Analysis Committee and the Company Quality Assessment Committee. Minutes of meetings of the cited bodies include an analysis of damages reported in the claim procedure, cause of the abnormality, indication of responsible persons and conclusions aimed at increasing the quality of service and repairs.

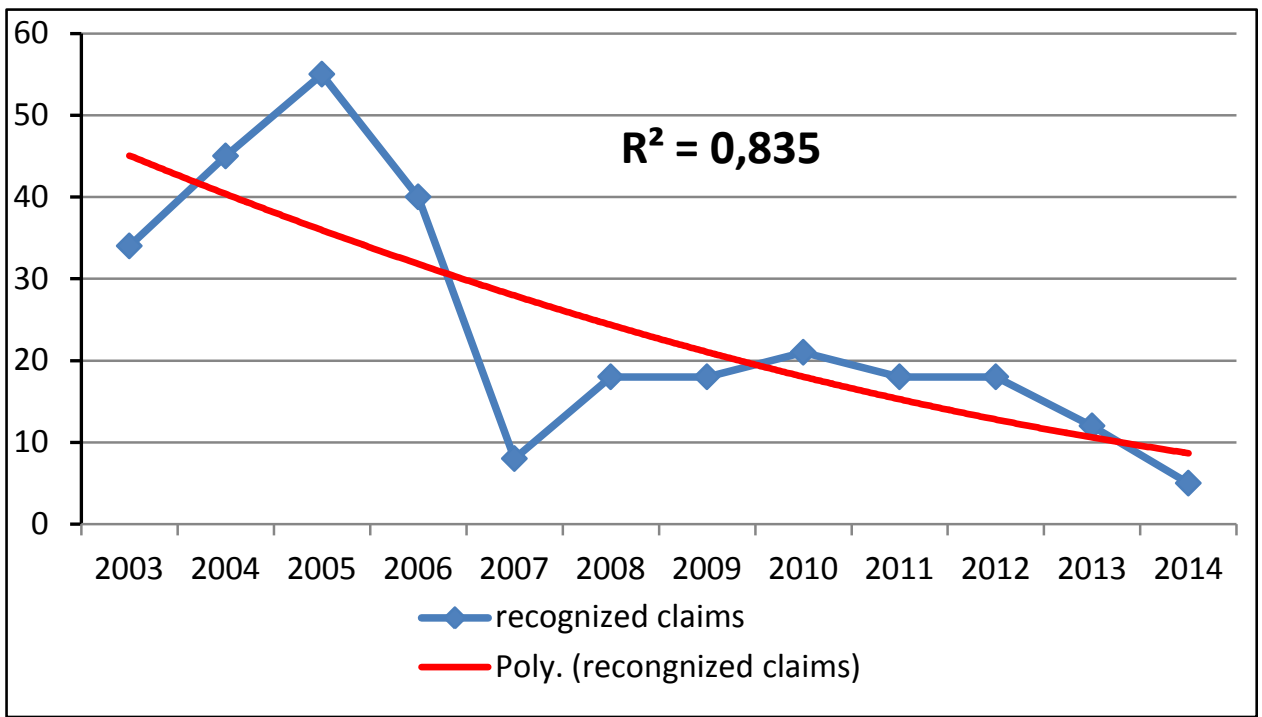

Fig. 6. Number of recognized claims submitted by users for the entire ACFT. [own elaboration on the basis of WZL (Military Aviation Works)-2 S.A. reports]

Graphs (fig. 7 to fig. 9) present the correlation between the number of accepted claims submitted by ACFT user for particular specialities: URE (RED Radioelectronic devices), Equipment, Weaponry and Airframe. In order to determine the temporal correlation, polynomial regression was used (obtained curves were approximated with second degree polynomials). The best correlation was obtained for the number of accepted claims reported by ACFT users for the RED speciality. 
Qualitative analysis of maintenance and services carried out in a repair plant... Analiza jakości obstug i napraw realizowanych $w$ zakładzie remontowym...

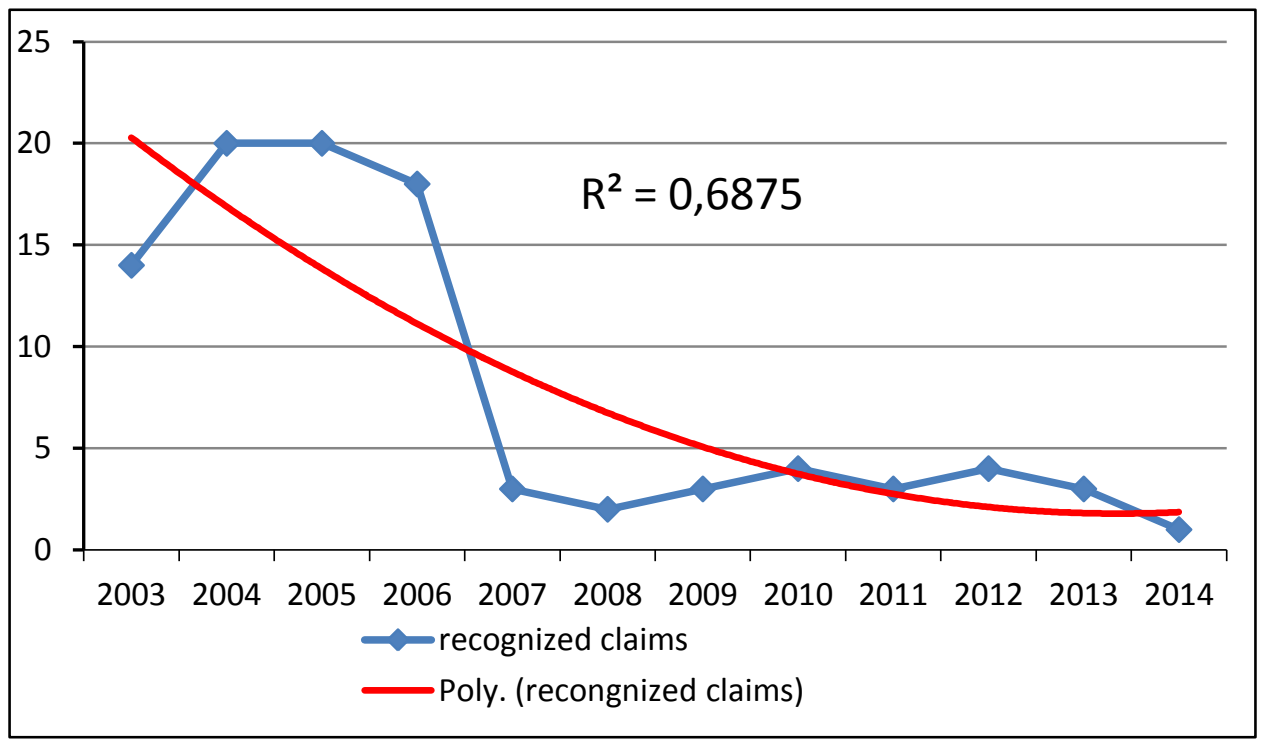

Fig. 7. Number of recognized claims submitted by ACFT users for the URE speciality [own elaboration on the basis of WZL-2 S.A. reports]

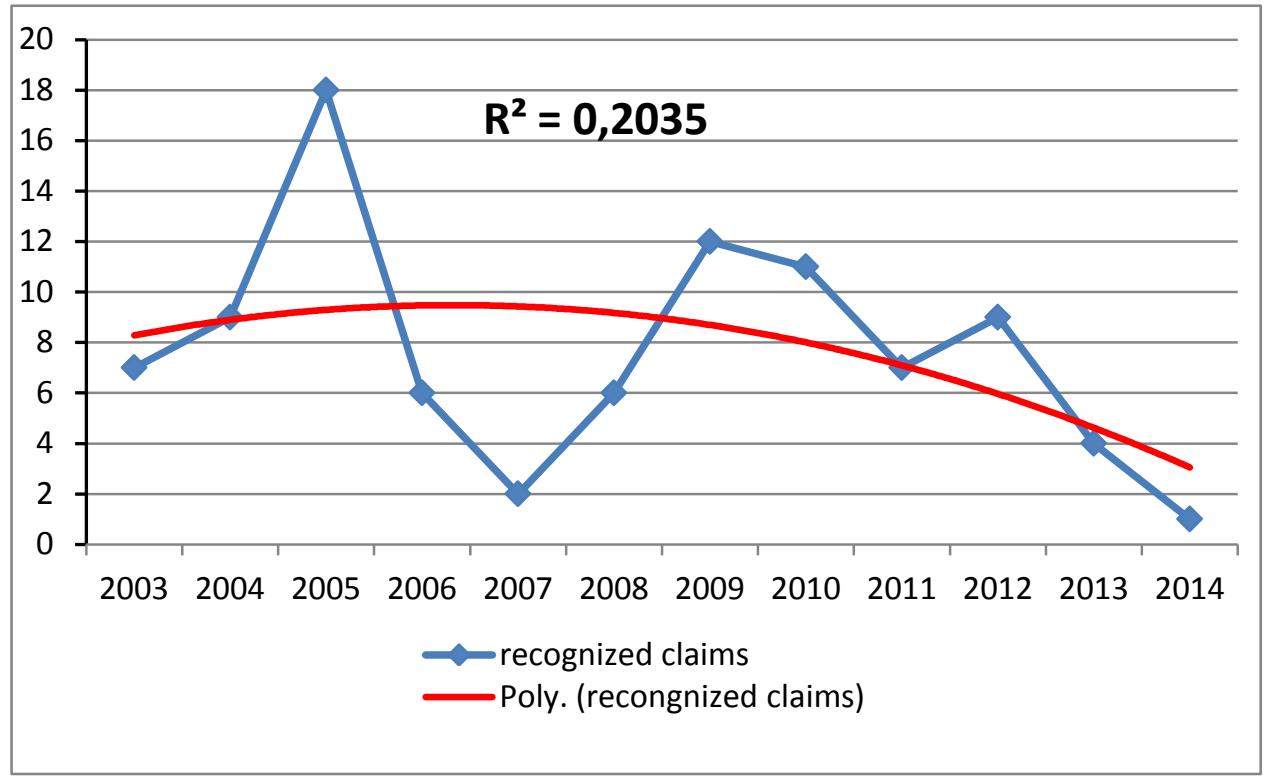

Fig. 8. Number of recognized claims submitted by ACFT users for the speciality EQUIPMENT [own elaboration on the basis of WZL-2 S.A. reports] 


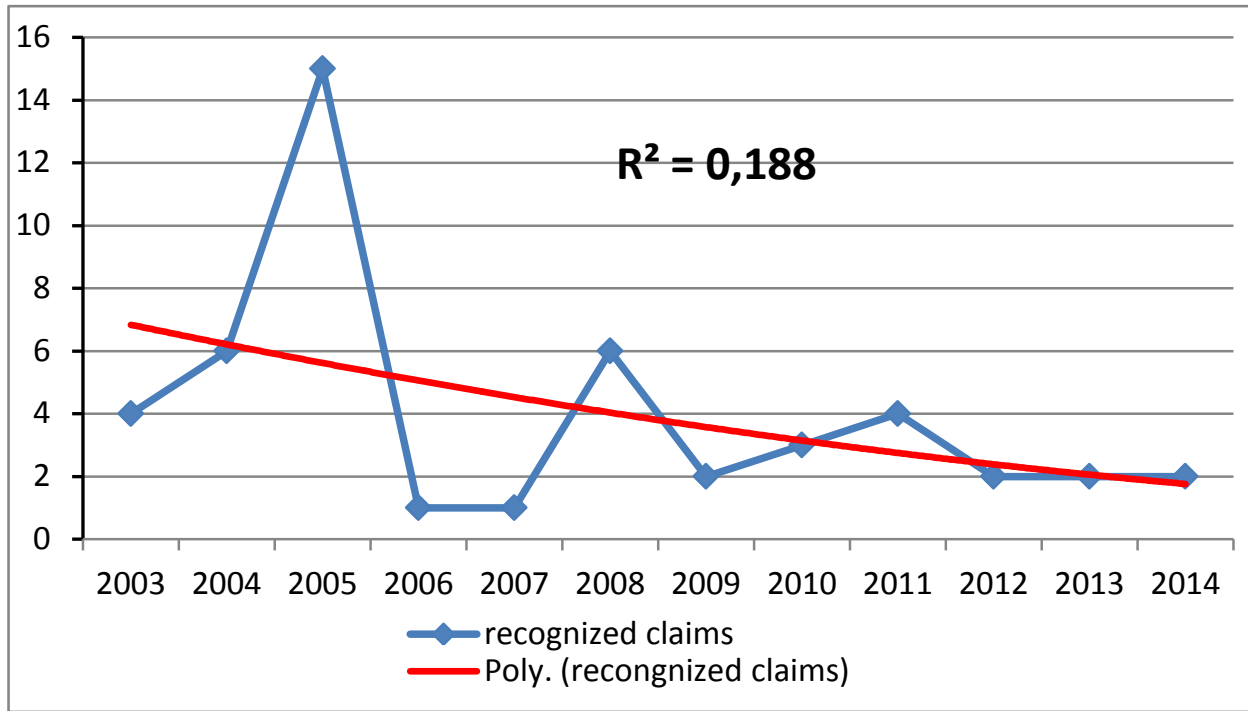

Fig. 9. Number of recognized claims submitted by ACFT users for the speciality AIRFRAME [own elaboration on the basis of WZL-2 S.A. reports].

\section{Summary}

Two areas clearly stand out in the evaluation of quality of technical operational actions. The first area is related to the human factor. i.e., correctness of using the ACFT and elimination of operational errors regarding ACFT repairs. Observed are malfunctions and failures typical, well known and described in documentation concerning operation and repair methodology. The second area are damages and malfunctions occurring rarely or ones that are identified for the first time during operation. New forms of damage can be of either, individual or systemic character. In damage prevention it is crucial correctly follow procedures during ACFT maintenance operations and correctly apply the repair process technology. Sometimes, only the revealed damages become a reason for analysis, verification and update of the operational-technical documentation. Damages impact the performance of aviation tasks, safety and operation costs, which is why methods of evaluating the ACFT repair and maintenance process should be developed and improved on the basis of damage analysis based on the theory of tribology, diagnostics, reliability and operation.

\section{Literature}

[1] Barszcz P., Błachnio J., Lewitowicz J., Michalak S.: Techniczna analiza niesprawności i uszkodzeń, W książce Podstawy eksploatacji statków powietrznych, pod red. [Technical analysis of malfunctions and damages, In the book Fundamentals of aircraft operation, ed.] J. Lewitowicz. Wydawnictwo ITWL, Warszawa 2007. 
Qualitative analysis of maintenance and services carried out in a repair plant... Analiza jakości obstug i napraw realizowanych $w$ zaktadzie remontowym...

[2] Lewitowicz J.: Fizyczne aspekty niesprawności i uszkodzeń statków powietrznych. [Physical aspects of malfunctions and damages to aircraft]. Przegląd WLiOP, 2002.

[3] Migawa K.: Sterowanie gotowością w systemach eksploatacji środków transportu.[Controlling readiness in operation systems for means of transports] Doctoral dissertation. UT-P, Bydgoszcz 2013.

[4] Niziński S., Żurek J.: Logistyka ogólna. [General logistics]. Wydawnictwa Komunikacji i Łączności, Warszawa 2011.

[5] Raporty WZL-2 S.A. z lat 2003-2014. [WZL-2 S.A. reports for 2003-2014]

[6] Tomaszek H., Jasztal M., Zieja M. A simplified method to assess fatigue life of selected structural components of an aircraft for a variable load spectrum. Eksploatacja i Niezawodność - Maintenance and Reliability 2011; 4, ss. 29-34.

[7] Woropay M.,Wdzieczny A., Bojar P., Szubartowski M.: Metoda oceny wpływu skuteczności realizowanych napraw na niezawodność i bezpieczeństwo działania systemów transportu miejskiego.[Methodology of analysing the influence of effectiveness of carried out repairs on reliability and operational safety of urban transport systems]. ITeE, Radom 2008.

[8] Woźny P., Błachnio J.: Wymagania jakościowe w procesach obsług oraz napraw statków powietrznych [Quality requirements in service and repair processes of aircraft], Prace naukowe ITWL, 2014, No 35, ss. 39-52.

[9] Woźny P., Błachnio J.: Analiza uszkodzeń powstających w procesie eksploatacji statków powietrznych [Analysis of damages arising in the process of operating aircraft]. Journal of KONBiN 2014; 4(32), ss. 73-86.

[10] Zieja M.: Metoda oceny trwałości wybranych urządzeń lotniczych wojskowych statków powietrznych [Methodology for assessing the sustainability of selected aeronautical devices of military aircraft] Problemy utrzymania systemów technicznych [Problems with maintaining technical systems] Warszawa: Oficyna Wydawnicza Politechniki Warszawskiej, 2014, ss. $151-160$.

[11] Żurek J., Smalko Z., Zieja M.: Methods applied to identify causes o fair events. Safety,reliability \& Risk Analysis - Theory and Applications vol. 3. CRC Press/Balkema Taylor \& Francis Group. London 2010.

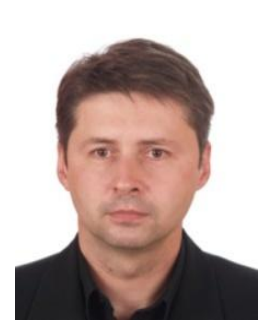

Piotr Woźny, M.Sc., is a specialist metrologist at the Military Aviation Works no. 2 S.A. in Bydgoszc. His are of interest are measuring diagnostic methods used in the process of repairing and service of ACFT and the measurement quality in operational processes. 